\section{Research Article}

(c) 2020 Asma Raies.

This is an open access article licensed under the Creative Commons Attribution-NonCommercial 4.o International License (https://creativecommons.org/licenses/by-nc/4.o/)

\title{
Islamic versus Conventional Fiscal policy: The Effect of Zakat on Education and Employment
}

\author{
Asma Raies \\ College of Business of Umm Al-Qura University, \\ Makkah, Saudi Arabia; \\ FSEG, University of Sfax, Tunisia
}

Doi: 10.36941/ajis-2020-0oo3

\begin{abstract}
Zakat is one of the pillars in Islam. It is the portion of a man's wealth designed for the poor. It is deemed to empower eight specific groups in society, i.e. the poor, the needy, those in debt, those in the wayfarer, the sympathizers, those in the cause of God, those in bondage and the fund administrators. The main goal of Zakat is to alleviate poverty through assistance to the poor and the needy and to achieve socioeconomic justice by closing the gap between the poor and the rich in the society. This paper focuses on the effect of Zakat on employment namely the effect of subsidising education of individuals who fulfil the criteria to be recipients of Zakat, thought taxing rich workers who are above Nisab, on employment. We also compare this Islamic policy (zakat) with the conventional one (namely subsidising education of all individuals by taxing their wages) used by most of countries and evaluates the effectiveness of both fiscal systems in reducing unemployment. We develop a theoretical neoclassic model showing that the conventional fiscal policy does not affect employment, which may justify the persistence of high unemployment rates observed in many developed and developing countries despite the massive public resources devoted to the education sector in these countries. The model proves that the Islamic fiscal policy will reduce unemployment.
\end{abstract}

Keywords: zakat; employment, taxes, subsidies, conventional fiscal policies, Islamic fiscal policy

\section{Introduction}

Being convinced by the necessity of increasing per worker human capital, governments in both developing and developed economies have massively invested in the education and training of their labour force populations by devoting increasing resources to the educational sector. As a result, while per worker human capital investment has considerably increased over the last two decades in most of these countries; unemployment rates remain still high especially in many developing countries. In addition, while unemployment hits primarily unskilled workers in developed countries, it hinders the most educated populations in the developing countries so that the huge and increasing flows of educated populations in these economies become a growing concern.

The present paper attempts to explain this reality by modelling the Islamic fiscal policy (zakat) and comparing it with the conventional one and evaluates their contributions in reducing unemployment.

One of the pillars in Islam is Zakat which is portion of a man's wealth (if wealth exceeds the minimum threshold called Nisab equivalent to the market price of $85 \mathrm{~g}$ of gold) which is designed for the poor. (see appendix). Zakat is deemed to empower eight specific groups in society, i.e. the poor, 
the needy, those in debt, those in the wayfarer, , the sympathizers, those in the cause of God, those in bondage and the fund administrators. (Sayyid Sabiq (1991), Bakar and Rahman, (2007) Ghani and Said. 2011). The main goal of Zakat is to alleviate poverty through assistance to the poor and the needy (Hassan (2010), Kahf (1999), Bakar and Rashid, (2010) and Wahab and Rahman (2011)), and to achieve socioeconomic justice by closing the gap between the poor and the rich in the society (Rashidah and Awang, 2003) and (Bakar and Rahman, 2007). By doing, zakat has been identified as an important source of financial seed to jumpstart the economy of the Muslim community (Anita et al., 2011).

For that reason, every Muslim and Islamic personality should play sincere roles in developing awareness among the mass people of Muslims (Hoque et al. 2013a; Hoque et al. 2014 and 2015) to pay their zakat to be used in development of educational and health care projects as long as the beneficiaries of such projects fulfil the criteria to be recipients of Zakat (Hassan, 2010).

The theoretical framework we develop in this paper shows that the conventional fiscal policy (namely subsidising education of all individuals by taxing their wages) used by most of countries has no effect on unemployment. However, the Islamic policy (Zakat paid only by rich and spent in subsidising education of only poor who fulfil the criteria to be recipients of Zakat) reduces unemployment.

The paper is organised as follows. In the second section we present a theoretical framework which models the firm's decision of labour demand, the worker's decision of human capital investment and the equilibrium of the economy. In the third section we evaluate and compare the Islamic and conventional fiscal policies.

\section{The Model}

We consider a closed economy composed of one production sector with a large number of perfectly competitive identical firms which produce a single good, $Y$, using labour and capital. We assume a fixed number (normalized to unity) of identical active individuals with human capital level $h$. Firms maximize their profit by fixing the total firms' labour demand, noted by $L$ which stands simultaneously for employment rate and the same probability to be employed for all individuals.

\section{Investment in Human Capital}

The representative individual is endowed with one unity of labour and he decides about his human capital investment $(h>1)$ by maximizing their expected labour income. The probability to find a job is the same for all individuals.

- Investment in human capital entails the cost, $\phi$, with $\phi(h)=b h$, where $b$ is a positive parameter indicating the per unity cost of human capital.

- The employed individual gains a wage, $w(h)$, which is increasing with his/her human capital, $h$. we also assume that there are no unemployment benefits as observed in most of developing and Islamic countries.

- We adopt the specification $\varepsilon w=a h$, where the parameter $a(a>0)$ indicates the per unity returns of human capital where $\varepsilon(0<\varepsilon<1)$ is the "individual" marginal return of human capital. This specification reflects the decreasing marginal return of human capital established, by Mincer (1974), Psacharopoulos (1994) and Psacharopoulos and Patrinos (2004).

- The expected surplus function of a risk-neutral individual with job uncertainty is thus defined as following:

$G=L w(h)+(1-L) \cdot 0-\phi(h)$

That is, each individual earns, a wage $w(h)$, with the probability $L$ and has to subtract the cost of investing in education, $\phi(h)$. Consequently, the equation (1a) re-writes:

$$
G=L\left(a h^{\varepsilon}\right)-b h
$$


This individual has to decide about the optimal investment in human capital that maximizes the surplus function ( $\mathrm{lb}$ ) given the cost of education and the employment rate. The human capital supply of this individual is given by the following function:

$$
h=\left[\frac{\varepsilon a L}{b}\right]^{\frac{1}{1-\varepsilon}}
$$

As a result the individual investment level in human capital decreases with the per unity human capital cost, $b$. It increases with the return parameters of this investment, $a$, and $\varepsilon$ and with the probability of being employed (i.e. the employment rate).

\section{Firms' Technology}

The representative firm has the following production function:

$$
Y=f(L, K)=A(h L)^{\beta} K^{\gamma}
$$

where $A$ is the exogenous technological progress and $\beta+\gamma=1$. By assuming the price of output equals 1 , the program of a firm writes:

$$
\max _{L, K} \Pi=Y-\left(a h^{\varepsilon}\right) L-r K
$$

where $r$ is the capital price.

First order conditions imply that the demanded quantities of capital and labour are such that their marginal products equal their prices. Thus we have:

$$
\begin{aligned}
& K=(\gamma A / r)^{1 / \beta} L h \\
& L=\frac{\beta Y}{a h^{\varepsilon}}
\end{aligned}
$$

By replacing expressions (3) and (5) into (6), we obtain the following expression of the employment rate:

$$
L=\frac{\beta A^{\frac{1}{\beta}}(\gamma / r)^{\frac{\gamma}{\beta}}}{a h^{\varepsilon}}
$$

\section{Equilibrium of the Economy}

Equations (2), (5) and (6) describes the economy and shows how endogenous variables mutually interact. By solving this system we can determine the equilibrium levels of human capital investment, $h^{*}$, employment rate $L^{*}$, and capital, $K^{*}$ :

$$
\begin{aligned}
& \left\{\begin{array}{l}
h^{*}=\Omega \varepsilon / b \\
L^{*}=a^{-1} \Omega^{(1-\varepsilon)}(b / \varepsilon)^{\varepsilon} \\
K^{*}=(\gamma A / r)^{1 / \beta} L^{*} h^{*}
\end{array}\right. \\
& \text { where } \quad \Omega=\beta A^{1 / \beta}(\gamma / r)^{\gamma / \beta}
\end{aligned}
$$

\section{Analysis of Fiscal Islamic and Conventional Policies}

In this section we study the effects of the conventional fiscal policy namely subsidizing education of all individuals by taxing their wages and the Islamic fiscal policy namely taxing rich workers whose 
wages are above Nisab to subsidise education of only poor (zakat). The former policy is adopted by most of developed and developing countries whereas the latter is not adopted yet even by Islamic countries themselves.

\subsection{The effects of the conventional fiscal policy}

It is assumed that the government subsidizes the education cost paid by all individuals at a rate of, $\eta$, so that they pay a net cost equals to $(1-\eta) b h$ instead of $b h$. Total subsidies, $\eta b h$, are financed through a proportional tax, $\tau$, levied on the wages of all workers.

This policy has two opposite effects on human capital, $h$ :

i) An encouragement effect stemming from a reduced education cost which increases individuals' gain $G$;

ii) A discouragement effect associated with wage taxation which reduces the individual's expected gain $G$.

The equilibrium of the government's budget implies that total investment in education should be equal to total taxes on labour-income. That is, the following equality should hold at this equilibrium:

$$
\tau w L=\eta b h
$$

thus

$$
\tau=\frac{\eta b h}{a h^{\varepsilon} L}
$$

Now the expected gain of a representative worker (equation $1 b)$ rewrites

$$
G=L\left(a h^{\varepsilon}\right)(1-\tau)-(1-\eta) b h
$$

Substituting (8b) in (9) gives the same gain function as (1b)

$$
G=L\left(a h^{\varepsilon}\right)-b h
$$

The individual's gain function remains unchanged after this policy. This implies that the negative discouragement effect of tax offsets the positive encouragement effects of education subsidies. This implies zero effect on the human capital supply function of these workers (given by equation (2)). In addition, as this policy concerns only workers, the firms' behaviour will not change too and the equilibrium remains unchanged. This result suggests that the conventional fiscal policy adopted by most of countries has no effect on employment which can justify the persistence of unemployment observed in these countries.

\subsection{The impact of the Islamic fiscal policy (Zakat)}

Let there be two groups of individuals in the society:

- Rich individuals whose wages are above Nisab are obliged to pay Zakat as exogenous fraction $z$ (given by Shariaa in appendixı) of their wage with a post zakat net wage equals to $(1-z)\left(a h_{r}\right)^{\varepsilon}$.

- Poor individuals whose wages are below Nisab don't pay zakat and benefit from education subsidies as fraction $\eta$ of their education cost ${ }^{b h_{p}}$ with a post zakat net cost equals to $(1-\eta) b h_{p}$.

Where $h_{p}$ and $h_{r}$ are respectively human capital investments of poor and rich respectively. Let $R$ the fraction of rich and $(1-R)$ the fraction of poor.

Under this Islamic fiscal policy regime, the government's budget equilibrium implies:

$$
R z\left(a h_{r}\right)^{\varepsilon} L_{r}=(1-R) \eta b h_{p}
$$


hence

$\eta=\frac{R z\left(a h_{r}\right)^{\varepsilon} L_{r}}{(1-R) h_{p}}$

The expected gain functions of rich and poor (equation $\mathrm{ib}$ ) become respectively now:

$$
\begin{aligned}
& G_{r}=(1-z) L_{r}\left(a h_{r}\right)^{\varepsilon}-b h_{r} \\
& G_{p}=L_{p}\left(a h_{p}\right)^{\varepsilon}-(1-\eta) b h_{p}
\end{aligned}
$$

Substituting (1ob) in (11b) gives the same poor's gain function as ( $1 \mathrm{~b})$

$$
G_{p}=L\left(a h_{p}^{\varepsilon}\right)-b h_{p}
$$

The human capital supply functions (2) rewrite respectively for rich and poor:

$$
\begin{aligned}
& h_{r}=\left[\frac{\varepsilon a L_{r}(1-z)}{b}\right]^{\frac{1}{1-\varepsilon}} \\
& h_{p}=\left[\frac{\varepsilon a L_{p}}{b}\right]^{\frac{1}{1-\varepsilon}}
\end{aligned}
$$

This policy has:

i) A discouragement effect associated with rich's wage taxation (zakat) which reduces their expected gain, $G_{r}$, and thus their human capital investment ${ }_{r}$ given by equation (13a). .

ii) An encouragement effect stemming from a reduced education cost for poor which increases their gain, ${ }^{G_{p}}$. However this effect is offset by the first one which implies zero effect on the human capital supply function of poor workers (given by equation (13b).

Accordingly, the new system $\left(S_{1}^{*}\right)$ writes as follows:

$$
\left\{\begin{array}{l}
h_{p} *=\Omega \varepsilon / b \\
h_{r} *=\Omega \varepsilon(1-z) / b \\
h^{*}=R h_{r} *+(1-R) h_{p} * \\
L_{p}^{*}=a^{-1} \Omega^{(1-s)}(b / \varepsilon)^{s} \\
L_{r}^{*}=a^{-1} \Omega^{(1-s)}(b / \varepsilon(1-z))^{s} \\
L^{*}=R L_{r}^{*}+(1-R) L_{p}^{*} \\
K^{*}=K^{*}=(\gamma A / r)^{1 / \beta} L^{*} h^{*}
\end{array}\right.
$$

The employment rate among higher educated (rich) workers, ${ }^{L_{r}}{ }^{*}$ in system $\left(S^{*} 1\right)$, is higher than in system $\left(S^{*}\right)$ which is due to the decrease in their human capital investment, $h_{r}$ making their wage relatively lower and thus enhancing firms to hire more workers from this group. However, the employment rate among lower educated (poor) workers, ${ }^{L_{p}}{ }^{*}$, is the same. Thus, the average employment rate $L^{*}$ is higher in system $\left(S_{1}^{*}\right)$ than in system $\left(S^{*}\right)$ suggesting the efficiency of the Islamic fiscal policy in reducing unemployment.

\section{Conclusion}

Our model shows that subsidizing education of all individuals through taxing wage - the conventional policy adopted by most of countries- has no effect on the employment rate which can justify the 
persistence of unemployment observed in many countries despite the massive public resources devoted to the education sector in these countries. However, it displays a positive effect of the Islamic fiscal policy on employment. In fact, we show that, subsidising education of only poor by Zakat levied only on rich's wages could reduce unemployment especially of the most educated. Although the results of this paper are theoretically, empirical examination should be conducted for future research.

\section{References}

Al-Qaradawi, Y. (1973). "Fiqh al Zakah” (Arabic). Beirut: Mu’assasat al Risalah

Ali, I, \& Hatta, ZA. (2014)." Zakat as poverty reduction mechanism among the Muslim coummunity: case study of Bangladesh, Malaysia, and Indonesia". Asian Soc Work Policy Rev, 8(1), 59-70.

Alvarez, SA, \& Barney, JB. (2014). "Entrepreneurial opportunities and poverty alleviation". Enterp Theory Pract, 38(1), 159-84.

Anita, Md Shariff et al. (2011): "A Robust Zakah System: Towards a Progressive Socio-Economic Development in Malaysia." Middle-East Journal of Scientific Research 7, no. 4 : 550-554.

Bakar, N and Rahman, A “A Comparative Study of Zakah and Modern Taxation” J.KAU: Islamic Econ., Vol. 20 , No. 1, pp: $25-40$

Bakar, N and Rashid, H. (2010) "Motivations of Paying Zakat on Income: Evidence from Malaysia". International Journal of Economics and Finance, Vol. 2, No. 3; August 2010.

Ghani, K and Said, J. (2011). "Carter Instrument for Zakat Organisation: An Examination using Delphi Technique”, Research Journal of International Studies - Issue 21 October, pp: 138-144

Hassan, K. (2010). "An integrated poverty alleviation model combining zakat, awqaf and micro-finance, Seventh International Conference - The Tawhidi Epistemology: Zakat and Waqf Economy, Bangi - Malaysia 2010

Hoque, N, Khan, MA \& Muhammed KD (2015)," Poverty alleviation by Zakah in a transitional economy: a small business entrepreneurial framework", Journal of Global Entrepreneurship Research, 5:7

Hoque, N, Ali, MM, \& Rahman, BMM. (2013a). "Islamic resurgence movements in bangladesh: experiences from Iran and Turkey". World J Islamic History Civilization, 3(2), 73-84.

Hoque, N, Khan, MA, \& Mowla, MM. (2013b). "Organisational culture: features and framework from Islamic perspective". Humanomics, 29(3), 202-19.

Hoque, N, Mamun, A, \& Mamun, AMA. (2014). "Dynamics and traits of entrepreneurship: an Islamic approach". World J Entrepreneurship, Manag Sustainable Development, 10(2), 128-42.

Kahf, M. (1999). The principle of socio-economic justice in the contemporary fiqh of zakat. The Iqtisad, University Islam Indonesia: CIESD

Mincer, J., (1974), “Schooling, experience and earnings”, New York: Columbia University Press

MINCER J. [1991], "Education and unemployment", NBER Working Paper $n^{\circ} 3838$

Mincer, J. (1994) "Human Capital: A Review." In Clark Kerr et al. (eds) Labour economic and Industrial Relations: Markets and Institutions. Cambridge: Harvard University Press

Psacharopoulos, G., (1994), "Returns to investment in education: A global update", World Development 22, 9, 132543.

Psacharopoulos, G., and Patrinos, H.A.,(2004), "Returns to investment in education: A further update", Education Economics, 12, 2, pp 111-134

Rashidah, R and Awang, R. (2003). "Assessing Business Zakat at Pusat Zakat Selangor: Between Theory and Practice", Journal of Financial Reporting and Accounting, Vol. 1 Issue: 1, pp.33- 48

Wahab, NA, \& Rahman, ARA. (2011). A framework to analyse the efficiency and governance of zakat institutions. Journal of Islamic Accounting Business Res, 2(1), 43-62. 


\section{Appendix}

Table 1 Nisab and Rates of Zakah for some of the contemporary items

\begin{tabular}{lll}
\hline & Rate & Nisab \\
\hline Cash & $2.5 \%$ & Equivalent of $85 \mathrm{~g}$ of Gold \\
Bank Deposits & $2.5 \%$ & Same as for cash \\
Stocks in Trade & $10 \%$ & Same as for cash \\
Agricultural Produce & $5 \%$, if investment is made in inputs and irrigation & 653 KG \\
Real Estate & $2.5 \%$ from their income & \\
Professionals & $2.5 \%$ from their income after deducting cost & Same as for cash \\
Shares/Stocks & $10 \%$ When dealing in the trading of shares & Same as for cash \\
& $2.5 \%$ from income if for the purpose of investment & Same as for cash \\
\hline
\end{tabular}

Source: Al-Qaradawi (1973) 